\title{
Barros, Rodrigo Lopes de, dir. (2015). Chacal: proibido fazer poesia [video digital, 24'13"']. Brasil ${ }^{*}$
}

\author{
Vanessa Moraes, Universidad de Brasilia \\ quantasvanessas@gmail.com
}

Rodrigo Lopes de Barros lançou, em meados de 2015, seu terceiro filme, Chacal: proibido fazer poesia, homenageando o poeta marginal Ricardo Chacal. Sendo exibido em festivais, vem recebendo seu devido reconhecimento crítico e sendo premiado. O diretor é professor de Literatura Hispano-Americana e Brasileira da Boston University. Graduado em Direito, mestre em Teoria Literária e doutor em Literatura Hispânica, nunca deixou de lado o cinema e, devido a essa paixão paralela, vem se aperfeiçoando nas técnicas cinematográficas. Seu primeiro filme, Há vida após a modernidade?, de 2005, trata-se de um documentário experimental. Depois, em 2012, lançou O corpo, uma narrativa que explora as incertezas de dois personagens diante de seus próprios corpos e um cadáver. O roteiro, a atuação e a trilha deste são de João Pedro Garcia, nome que reaparece no filme sobre Chacal assinando a trilha. O terceiro filme de Rodrigo Lopes de Barros traz uma novidade em relação a seus primeiros trabalhos: a poesia. Guilherme Trielli Ribeiro assina, junto com o diretor, a produção e o roteiro. Já a fotografia fica por conta de Maria del Mar Bassa e Lopes de Barros, e contribui significativamente para a beleza das minúcias de Chacal, assim como para o conjunto geral das imagens.

Para a produção, o diretor optou por mesclar fragmentos de textos, imagens e sons numa linguagem bastante poética. Durante a edição do filme, ele ministrava um curso na Universidade de Boston sobre Cinema Cubano dos anos 1960. Suas opções estilísticas nesse curta-metragem dialogam, nesse sentido, com a ideia de montagem improvisada e imperfeita do cinema cubano, que muito o influenciou. Além disso, os realizadores produziram esse filme tirando a força criativa da escassez, uma vez que não tiveram apoio financeiro do Estado (apenas contaram com o apoio dos programas de literatura das universidades de Harvard e de Boston).

O filme trata de poesia, mas não deixa de ser uma. Tem início com o cumprimento do poeta e com trechos informativos que atualiza o espectador e deixa claro a que o filme veio: "Em abril de 2014, o poeta Chacal, convidado por Harvard, passa uma semana nos EUA, onde apresenta sua arte de poeta e performer. Ele se empenha num balanço memorialístico, ligado à Poesia Marginal (Geração

*Recibido: 10 de marzo de 2016/ Aceptado: 30 de mayo de 2016. 
Mimeógrafo), à Tropicália e ao rock". Com os fragmentos expostos na tela, somos levados a uma aula do que foi a (contra)cultura, a poesia marginal e a ditadura, nesse contexto da arte no Brasil. E vamos percebendo o quão utópico e revolucionário foi esse movimento de artistas dos anos 60 e 70, além do quão performático e ousado foi Chacal, que nos mostra ser possível reviver a experiência estética desse período a partir de sua poesia, de sua leitura, de sua interpretação, de seu gestual. Revivemos um pouco da poesia tal como era em sua origem: recitada, performática, cantada, encenada, declamada, experienciada, ouvida. O filme capta isso muito bem: o poeta faz a plateia se manifestar, se "incomodar", ser afetada pela poesia. A poesia se dá através da fala, mas também do corpo, tal como o pensador Paul Zumthor propunha. O corpo é o que escapa ao controle, mesmo numa tentativa de disciplinarização. Ele não se integra diretamente ao eu nem ao grupo, mas, dentro da performance, acontece à margem, num escape, e esse processo fugidio e de transbordamento constitui-se a presença, a percepção. Mas a performance exige o reconhecimento da situação comunicativa, já que o texto é teatralizado, e por isso vemos Chacal querendo resposta da plateia. Quando não percebe reações, recita novamente até ficar satisfeito. Assim fica explícito que não há experiência estética em que o "agente" não seja um experimentador, para falar com Zumthor. Rodrigo Lopes de Barros experienciou/experimentou tudo aquilo juntamente com Chacal e com a plateia que ali fazia parte do processo. E mais uma vez explorou o corpo. Outro corpo, outra história, outro contexto. Outro filme tocando o corpo. Afetando e sendo afetado (no sentido mesmo de afeto).

Em alguns trechos, o filme pode suscitar sensações e outras leituras, mesmo que não propositais. Exemplifico com a passagem em que foi lido o poema "Ópera de Pássaros". Ao fundo, a voz que recitava: "A-o / A-o / A-objetividade da fotografia é uma falácia". E o que vemos na tela são recortes, uma montagem de fragmentos de fotografias de pessoas diferentes que se juntam formando um novo ser, uma mistura racial. E o poema continua: "erram os que acham que ela retrata o real". De fato, a fotografia é falaciosa, um simulacro; e tal noção pode remeter à ideia do cachimbo, de René Magritte. Isso não é uma pessoa, poderia dizer Chacal. Mas ele brinca com o clichê dos fotógrafos "olha o passarinho!", inovando e criando situações inusitadas para o poema -passa a mensagem com humor e teatralidade.

A peça-chave do filme é a utopia. Chacal lembra que na passagem dos anos 1960 para os 1970, as utopias pareciam ter caído por terra: "as utopias ruíram?", pergunta-se. E responde com a célebre declaração de John Lennon: "o sonho acabou". Morreram Hendrix, Joplin, Morrison. Não havia mais saída. Era como se as utopias tivessem realmente acabado. Em terras brasileiras, a censura define a nova geração, inclusive a poesia marginal. Chacal classifica esse período como 
pós-hippie/proto-punk, pois é o fim da geração "paz e amor" e início de uma época de uma moçada mais revoltada. Lembra que hoje em dia, felizmente, tem muita gente se mobilizando, lutando, e, no seu modo de ver, parece que a utopia está voltando entre os jovens dessa nova geração.

Os artistas desse período, em geral, são admirados por Chacal -fossem marginais ou não. Cita algumas discordâncias entre ele e Wally Salomão e também entre ele e Paulo Leminski, mas naquele momento de luta, sempre estavam do mesmo lado. Era proibido fazer poesia, mas ele fazia. Driblava a polícia. E se unia a outros movimentos artísticos, como o concretismo, em nome da luta contra a ditadura. Lutava, escrevia, era movido pela utopia. Admirava Oswald de Andrade, com seus poemas enxutos e seu Manifesto Antropófago. Juntava-se com eles, independente se os poetas eram do modernismo ou do concretismo. Ele dizia: "A arte é o estopim da revolução. [...] Godard não era tão paz e amor assim...". Lopes de Barros vai sobrepondo o que Chacal vai dizendo e destacando suas mensagens na tela: "proibido ser feliz / proibido ficar doidão / proibido ter cabelo comprido". E a repetição mais enfática na mensagem: "proibido fazer poesia / proibido fazer poesia / proibido fazer poesia".

O contexto político da produção poética que é enfatizado no filme é o ditatorial. A ditadura no Brasil (1964-1984) foi um período marcado pelo autoritarismo militar, pela prática de vários Atos Institucionais (Al) que "regulamentavam" perseguições políticas, censuras, supressão dos direitos constitucionais, repressão aos que ousassem discordar do regime militar, além do descumprimento da democracia. Em 31 de março de 1964 acontece o Golpe Militar, que afasta o presidente eleito democraticamente João Goulart (Jango), sob a justificativa de que havia uma ameaça comunista no país. Entra no poder o Marechal Castelo Branco. O golpe de estado permite que se instaure a ditadura militar, que permanece até fim de 1984, quando Tancredo Neves se elege presidente do Brasil. O historiador Júlio José Chiavenato, em O golpe de 64 e a ditadura militar no país assinala como esse poder "em mãos erradas" foi infrutífero para o crescimento da nação: "Ostentavam poder e força, mas aliaram-se às elites da alta hierarquia socioeconômicas e 'andaram para trás', enquanto uma intensa propaganda dizia que o país caminhava para um grande futuro".

O "proibido fazer poesia" estava relacionado à censura do regime militar sobre os poetas, mas também se aplicava a artistas plásticos, compositores, cineastas, professores e quaisquer pessoas que ousassem se expressar contra o regime ditatorial. A ideia das perseguições, repressão e o exílio não davam trégua para os poetas. A válvula de escape, já que não se podia publicar nada através de editoras, era "rodar o mimeógrafo" e reproduzir os textos/poemas. A "liberdade" de expressão se adaptava como podia, era conquistada através de subterfúgios como o mimeógrafo. Daí a alcunha desses poetas marginais de "geração mimeógrafo". 
Chacal mostra alguns exemplares dos panfletos daquela época, como o de seu primeiro livro, escrito em 1971, que foi mimeografado com tiragem de 100 cópias. A poesia era urgente: faziam-se os livros enquanto a polícia corria atrás deles. Não havia calma nem acabamento.

As drogas não poderiam passar despercebidas. Quando Chacal recita "Meu primeiro poema psiquiátrico", imagens psicodélicas e pluralizadas "brotam" na tela e nos levam a uma visão também distorcida, que dialoga com o próprio poema. Num outro momento, a fluidez das cidades: quadros sobrepostos com imagens simultâneas confundem a lisergia dos ácidos descritos pelas palavras do poeta com a rapidez dos flashes que o diretor joga: versos, imagens das cidades em transformação, a urbe, o caos. E uma guitarra gritando ao fundo.

Ao falar de suas experiências no Rio de Janeiro dos anos 70, Chacal lembra a tríade sexo-drogas-rock'n'roll, na qual ele, literalmente, se envolvia com prazer. Entretanto, sobre as drogas, adverte que a mistura sensorial já vinha de Rimbaud: o desregramento total de sentidos. Chacal cita ainda o grupo carioca do qual participou, "Nuvem cigana", em que poetas, fotógrafos, compositores e artistas de diversas áreas, em plena ditadura, se reuniam, recitavam, compunham, formavam bloco de carnaval, iam beber nos botecos, jogavam futebol e, sobretudo, se envolviam em performances poéticas. Há uma composição de título homônimo ao grupo, de Ronaldo Bastos e Lô Borges, que possui os seguintes versos: "Se você deixar o sol bater / Nos seus cabelos verdes / Sol, sereno, ouro e prata / Sai e vem comigo...". Sim, o grupo queria essa sinestesia nos textos e no cotidiano.

A ousadia e personalidade de Chacal são traços fortes de quem enfrenta seus ideais e vive mesmo de utopia. O fragmento que aparece na tela com o neologismo "harvadiou" confirma essa hipótese: "Durante a visita, Chacal realizou performances, vocalizou poemas, gravou entrevistas, harvadiou pelo campus e arredores, vivendo a utopia da poesia à margem, irredutível a fórmulas e códigos de conduta, leis e normas estéticas". À margem, Chacal não seguiu o caminho editorial tradicional ou midiático; não fez poemas para fins comerciais, ficando, podemos dizer, "à margem da margem", uma vez que, por si só, ser poeta já é uma redundância de ser marginal. Ao se esquivar das publicações "regulamentadas", isso se intensifica. E Chacal é marginal até as últimas consequências: faz poesia quando "é proibido fazer poesia"; fuma um baseado quando a polícia "cai em cima" de qualquer maluco de cabelo comprido.

No que tange à corrupção cultural nesse contexto "pré-golpe militar", sabemos que em 1963 muitas publicações foram realizadas pelo GPE (Grupo de Publicações Editorais) com o intuito de deturpar o movimento comunista. Foram cerca de 300 mil livros e 40 mil informativos mensais com conteúdos de baixa qualidade. O boletim O Gorila, por exemplo, vinculava a ideia de comunistas a homens 
frios, traiçoeiros, assassinos. Vem daí também a repercussão de que todo comunista matava frade, estuprava freira, violava igreja e "comia criancinhas", como observa Júlio José Chiavenato. E Chacal desponta nesse cenário político: de repressão, de autoritarismo, de censuras. Sabemos, inclusive, que os intelectuais e artistas de destaque no meio cultural brasileiro eram forçados a dar depoimentos em emissoras de TV em que se mostravam coniventes aos atos políticos que aconteciam no país. Gilberto Gil e Caetano Veloso são exemplos disso. Além de exilados, tiveram seus longos cabelos raspados, as letras de suas canções passavam por uma triagem e eram modificadas, assim como as composições de Chico Buarque de Hollanda e outros tantos artistas de renome.

A poesia de Chacal teve então seus motivos para estar à margem. A liberdade de expressão, corrompida pela censura, não sucumbia; mas dava espaço a uma esperança cambaleante, como na canção de João Bosco e Aldir Blanc interpretada por Elis Regina: "a esperança / dança / na corda bamba de sombrinha / e em cada passo dessa linha / pode se machucar".

O filme se encerra com um poema que trata da vida-morte. O belíssimo "Vida" é, na realidade, um trocadilho que vai culminar na ideia da morte: "roer / moer / remoer / morrer". Chacal é genial. Seus pés descalços mostram que sua poesia nunca terá fim: "Vai ter uma festa / que eu vou dançar / até o sapato pedir / pra parar. //Aí eu paro / tiro o sapato / e danço o resto da vida". Chacal começou dançando com sapatos na década de 60, mas logo os retirou. Há muito tempo está descalço. E continua dançando pelo resto da vida.

\section{Seleções em festivais/premiações de Chacal: proibido fazer poesia:}

- Selecionado para o 12th Chicago International Art House Film Festival (Blow Up Film Fest).

- Selecionado para o 10ํㅡㄹ Miragem. Mostra de Cinema e Vídeo de Miracema - TO; para o Festival do Audiovisual de Belém - PA.

- Selecionado para o Festival de Cinema de Três Passos - RS e para a 15a Mostra do Filme Livre.

- Finalista do prêmio de Melhor Documentário de Curta-Metragem, "Lumière Brothers Award", 12th Chicago International Art House Film Festival (BlowUpFilmFest), em Chicago, 2015.

- Premiações pela melhor edição e melhor trilha sonora no Festival de Cinema de Três Passos - RS.

- Premiação no LASA Film Festival - Award of Merit in Film. 